\title{
Digestive Enzymes in Some Teleost Species of Interest for Mediterranean Aquaculture
}

\author{
G. Caruso, M.G. Denaro* and L. Genovese
}

National Research Council, Istituto per l'Ambiente Marino Costiero, Messina, Italy

*University of Messina, Department of Life Sciences “M. Malpighi”, Faculty of Sciences, Messina, Italy

\begin{abstract}
In intensive aquaculture, basic studies on fish digestive capacity and metabolism play a key role for diet formulation. In particular, intensive rearing of a new species is strictly related to the development of appropriate nutritional protocols and therefore knowledge of specific features concerning physiology and nutrition is needed. Nutrient utilization by fish is a direct function of the availability of suitable digestive enzymes along the gastro-intestinal tract. Therefore the determination of specific enzymatic activities (proteases, carbohydrases and lipases) may provide qualitative information about the digestive capacity and the efficiency of each reared species to use feeding components. Recent observations on digestive enzymatic profiles and on digestive ability of some Teleost species with large aquaculture potential and recognized as new candidates for product diversification have been reviewed in this paper. Attention has been given to the different features (dietary composition, digestive phases, life stages, contribution of bacterial .enzymes) that may affect enzymatic patterns.
\end{abstract}

Keywords: Digestion, enzymes, fish, diversification, new candidate species.

\section{INTRODUCTION}

Expansion of fish farming is strictly related to improvement in nutrition, fish welfare, and husbandry practices. Each of these topics represents a challenge for future development in aquaculture. Mass production of new species depends strongly on the elaboration of proper feeding protocols able to satisfy their nutritional requirements. Studies aimed at investigating the functioning of the digestive tract in different species can provide relevant tools for the optimisation of the relative percentage of their dietary macronutrients; therefore, knowledge of digestive enzymes of fish has important practical implications for their nutrition.

The ability of fish to metabolise a diet depends on the availability of appropriate digestive enzymes, which mediate specific degradation pathways, as well as on both physical and chemical nature of food [1]. The measurement of specific activities (proteases, carbohydrases and lipases) may provide information about the whole digestive capacity and the efficiency of species reared to use feeding components [2].

Digestion is a progressive process, that starts in the stomach and continues to take place along the intestine. By this process, ingested materials are hydrolysed into smaller size molecules, such as amino acids, simple sugars and fatty acids produced by the hydrolysis of proteins, sugars or lipids, respectively. Fish usually display high versatility in their

\footnotetext{
*Address correspondence to this author at the National Research Council, Istituto per l'Ambiente Marino Costiero, Spianata S. Raineri, 86 - 98122 Messina, Italy; Tel: +39-090-669003; Fax: +39-090-669007; E-mail: gabriella.caruso@iamc.cnr.it
}

feeding habit that is reflected in different anatomical and functional features; both nutritional and physiological characteristics allow them the exploitation of a wide range of food resources, thus improving their adaptation to changing environmental conditions.

Several studies [3-8] have previously shown that the distribution and activity of digestive enzymes within the gut are affected by feeding habits. Herbivorous fish usually possess a gut longer than carnivores and a digestive enzymatic profile adapted to feed ingredients, with the predominance of carbohydrases (i.e. amylases, disaccharidases), which allow them the hydrolysis of polysaccharides. Conversely, carnivorous fish have a short intestine, with higher levels of proteases compared with herbivorous fish, while also amylase $[6,9]$ and lipase $[10]$ are represented in minor percentage in their digestive tract. In fact, in the dietary composition of the most carnivorous fish, proteins and lipids play an important role as a source of basic nutrients and energy [11]. Moreover, a differentiation in enzymatic distribution within the digestive organs has also been observed; while food ingested is first hydrolysed in the stomach by the acid protease pepsin, alkaline enzymes (i.e. trypsin, chymotrypsin, carboxypeptidases, lipases) from the pancreas and the liver allow the progression of food digestion inside the midgut $[3,12,13]$.

Until now, comparative studies of the digestive enzymes in different fish species have been performed [6, 14-15]; nevertheless, fish digestive capabilities have not yet been completely investigated and this explains some difficulties in formulating dietary protocols responsive to fish metabolism. In particular, the inter-relationships between enzyme expression and control factors, such as the adaptive responses of 
the digestive enzymatic spectrum in relation to the dietary components or life stage, are still not clearly understood, stressing the importance of studies addressing these topics.

Several studies, performed in recent years in our laboratory, have focused on physiological and nutritional aspects related to fish farming. Particular attention has been given to the assessment of digestive abilities in fish species considered as "emerging" in aquaculture, in order to verify their potential as new candidates for aquaculture diversification. In fact, most of these species have high commercial value and/or offer interesting perspectives for market expansion especially in the Mediterranean area; nevertheless, only a few data on nutrient digestion are available in literature [6, 16-19].

The aim of the present review is to improve current knowledge of the amount and distribution of digestive enzymes mostly in species belonging to Sparidae family (axillary seabream, blackspot seabream, common pandora), but also species of Carangidae (greater amberjack) and Serranidae [dusky grouper Epinephalus marginatus (Lowe) and grouper, Epinephalus aeneus (Geoffrey St Hilaire)] were included in the research. In particular, some factors that may affect enzymatic patterns were investigated, such as:

-nature and composition of the diet, such as observation made in axillary seabream, Pagellus acarne (Risso) [20, 21] and in blackspot seabream, Pagellus bogaraveo (Brünnich) $[22,23]$.

-digestive phases, such as those studied in greater amberjack Seriola dumerilii (Risso) [24, 25] as well as in blackspot seabream [22].

-possible interaction between native, endogenous, enzymes and exogenous enzymes produced by microbial flora, such as that investigated in greater amberjack [26] and in blackspot seabream [27].

-life stages, with reference to changes occurring in enzymatic patterns during growth (as observed in larvae of common pandora, Pagellus erythrinus L [28].

-specific diversity, concerning some species belonging to Sparidae [20-22, 29] and Serranidae families.

\section{MATERIALS AND METHODOLOGY}

\section{Notes on the Biology of the Examined Species}

Greater amberjack (Seriola dumerilii) is a Carangidae species living in the Mediterranean Sea. It inhabits deep seaward reefs, occasionally entering coastal bays; it is a carnivorous species, feeding primarily on fishes and invertebrates. A nursery area for this species is the Aeolian Archipelago in Sicily.

Axillary seabream (Pagellus acarne), belonging to Sparidae, is a carnivorous fish widely distributed in the Mediterranean Sea; in the Straits of Messina it is frequent in sandy or muddy seabeds [30]. Juvenile stages occur in coastal environments, whereas adult specimens have pelagic and gregarious habits [31]. The high commercial value and the enhanced rhythm of growth make this fish a suitable species for intensive rearing [32].
Pagellus bogaraveo, belonging to Sparidae, is a species widely distributed in different temperate environments, including from inshore waters, above various types of seabed (rocks, sand, mud) to $400 \mathrm{~m}$ (Mediterranean Sea) and $700 \mathrm{~m}$ (Atlantic Sea). Young specimens are found near the coast, while adults inhabit the continental slope especially over muddy seabeds. It is omnivorous, but it prefers crustaceans, molluscs, worms and small fish; it displays rearing characteristics (i.e. fast growth) similar to other Pagellus species [33] and represents an important human food source.

Blackspot seabream (Pagellus erythrinus) is a popular table fish recently regarded as a new candidate species for aquaculture. It is found on inshore waters, on various seabeds (rock, gravel, sand and mud) to $200 \mathrm{~m}$ (Mediterranean Sea) or $300 \mathrm{~m}$ (Atlantic Sea), moving to deeper waters during winter. It is omnivorous, but feeds mainly on benthic invertebrates and small fish. Despite a growing commercial interest, only few studies regarding its biology, reproduction and larval rearing have been carried out $[34,35]$; in particular, the structural and biochemical modifications occurring during the ontogenesis of the digestive tract have never been investigated.

Dusky grouper (Epinephalus marginatus) and grouper (E. aeneus) are both carnivorous predators, feeding mainly on fish and molluscs. Concerning their ecological habitat, adult specimens are usually found on rocky or muddy-sandy seabeds, at depths between 20-200 m, whereas juveniles are frequently found in coastal lagoons and estuaries.

\section{Experimental Design and Samples Collection}

The study was carried out at the facilities of the Institute for Coastal Marine Environment of Messina.

For the experiments, young specimens of greater amberjack were caught with a circular net in summer, then acclimated (1-2 days) in floating cages before their transport to the Institute. They were kept in a $12 \mathrm{~m}^{3}$ PVC tank and fed an experimental live diet (Trachurus trachurus) supplemented with a commercial mineral-vitamin mixture, which was administered until satiation [25]. The experiment on this species was carried out on adult specimens (average weight: 500 $\pm 72.15 \mathrm{~g}$ ) in October 1994 (temperature, $18^{\circ} \mathrm{C}$ ), when fish were in an active phase of alimentation. Five fish were sacrificed at different time intervals from food ingestion, namely 2, 4 and 6 hours after, as well as after 2 days of starvation (fish taken as a control).

Specimens of axillary seabream were caught from the Straits of Messina in summer 1993 and acclimated for 15 days in cylindro-conical tanks having a capacity of $1.6 \mathrm{~m}^{3}$, with two daily changes of water and no forced aeration. Juveniles (mean initial body weight $45.6 \pm 2.6 \mathrm{~g}$ ) were divided in two experimental groups at a density of 8 fish $\mathrm{m}^{-2}$ and fed throughout the experiment with two diets: diet A, based on fish offal consisting of Trachurus trachurus supplemented with vitamins and mineral salts, and diet $\mathrm{B}$, consisting of commercial dry pellets for seawater carnivorous fish (TROUW NUTRITION SpA, Verona, Italy), administered daily at 20 and $10 \%$ of the fish live weight.

The composition of the basal diets (as percentage on dry basis) was: diet A, crude protein: 74.01, lipid 15.50, ash, 
11.22; diet B, crude protein: 35.87 , lipid 12.53 , crude fibre 2.20, N-free extract, 20.60).

Specimens were collected from each group, during October, when water temperatures ranged from 18.4 to $19.4{ }^{\circ} \mathrm{C}$.

Concerning blackspot seabream, a first experiment was performed in 2003 on reared juveniles (average weight: 91.6 $\pm 12.5 \mathrm{~g}$ ), in the framework of a research study aimed at evaluating the effects of different vegetable oils on the growth performances of this fish species. Juveniles were divided in three different groups and fed with different experimental diets, indicated as "fish", "linum" and "echium". "Fish" diet consisted of a standard diet containing fish oil (fish flour 55\%, corn flour $20 \%$, oil 7.5\%, crude starch $6.5 \%$, extruded soybean flour $5.5 \%$, crude fibre $5.5 \%$, mineral salts $3 \%$ ); "linum" and "echium" diets had been obtained by substituting the fish oil contained in the "fish" diet with linum and echium oils. A fourth group was fed a commercial dry diet for carnivorous fish (HENDRIX S.p.A., Mozzecane, Verona, Italy), and taken as a control. Diets were administered as $1.2 \%$ of the total body biomass calculated weekly. From each group, five specimens were sacrificed after 2 days of starvation as well as 4 hours after feeding, with the aim of studying changes in enzymatic distribution due to the progression of digestion.

A second experiment was carried out on blackspot seabream juveniles (average weight: $66.85 \pm 17.65 \mathrm{~g}$ ) in 2005, in order to investigate the effects induced on the digestive enzymes by the administration of two diets containing different levels $(20 \%$ and $35 \%)$ of rice protein concentrate as a protein source, in partial substitution of fish meal [23].

In common pandora, digestive enzymes were investigated at larval as well as at juvenile stages. Larvae were provided by COISPA (Bari, Italy), where they were intensively reared (initial density of $\sim 150$ larvae $\times 1^{-1}$; tank volume of $1.5 \mathrm{~m}^{3}$, temperature range: $18-19^{\circ} \mathrm{C}$ and a natural photoperiod) using pseudogreen water based on a mixture of microalgae Isochrysis galbana and Tetraselmis suecica [36]. Since the $3^{\text {rd }}$ Day After Hatching (DAH), diet was supplemented with Rotifers (Brachionus plicatilis; small strain), enriched in their fatty acid content through commercial emulsifiers (DHA SElCO, InVE AQUACULTURE, Dendermonde, Belgium). Further changes in the dietary composition were gradually performed, with some overlapping phases. Artemia nauplii were administered at the $28^{\text {th }}$ day while the artificial food $(\varnothing 544 \mu \mathrm{m})$ was introduced from the $35^{\text {th }}$ day onwards. Enzymatic measurements were performed at 0, 3, 6, 10, 17, 24, 31, 38 and 45 DAH (days after hatching).

A further study was carried out in 1999 on the digestive tract of common pandora juveniles (average weight: $200 \pm$ $19 \mathrm{~g}$ ) feed with an extruded diet (HENDRIX) [29].

In dusky grouper and grouper, digestive enzymes were studied on juveniles of $150 \pm 35 \mathrm{~g}$ (average weight) sampled after 2 days of starvation.

\section{Treatment of the Samples}

For the preparation of crude enzymatic extracts, whole digestive tracts were removed from fish specimens and divided into different portions (stomach, pyloric caeca and intestine), having cure of avoiding reciprocal contamination. After being weighted, they were homogenized with Potter in Tris buffer $50 \mathrm{mM} \mathrm{pH} 7.0$ (a volume 5 times the sample weight, w/v), and then centrifuged at $3000 \mathrm{rpm}$ for $10 \mathrm{~min}$ utes. The supernatant obtained was used as an enzymatic extract for further biochemical determination. All the operations were carried out at a temperature lower than $+5^{\circ} \mathrm{C}$.

For enzymatic measurements in larvae, specimens were sampled immediately before the food distribution, pooled and immediately stored at $-80^{\circ} \mathrm{C}$ until assays. A sample of food was also taken as a control. All the samples were homogenised in 5 volumes $(\mathrm{v} / \mathrm{w})$ of ice-cold distilled water, according to the protocol of Ribeiro et al. [37]; whole larvae were used for younger specimens, while from day 31 , the heads were removed and the remaining body portions pooled.

\section{Analytical Procedures for the Determination of Digestive Enzymes}

For the enzymatic assays on adult and juvenile specimens, a group of 5 fish were used for each species, while a total of 100 larvae were sacrificed to study the enzymatic distribution. Standard procedures for the determination of pepsin, trypsin and chymotrypsin, carboxypeptidase A and $\mathrm{B}$, leucine aminopeptidase, elastase, amylase, lipase, were followed. In particular, the substrates used to measure the activity of each proteolytic enzyme were the following: bovine haemoglobin (SIGMA-ALDRICH) for the determination of pepsin activity [38]; N-toluen-sulphonyl-L-arginine methyl ester and N-benzoyl-L-tyrosine ethyl ester (SIGMAALDRICH) as the substrates for trypsin and chymotrypsin [39], respectively; L-hippuryl-L-phenylalanine and Lhippuryl-L-arginine (SIGMA-ALDRICH) for carboxypeptidases A and B [40]. Elastase and leucine aminopeptidase were detected in the gastro-intestinal tracts of greater amberjack, axillary seabream, common pandora and grouper only, measuring the hydrolysis of L-leucyl-naphthyl-amide and elastin-orcein (SIGMA-ALDRICH), respectively [41, 42]. Total proteases were measured using a non-specific assay (Kunitz' s method [43], and its further modification [44]), based on the use of casein (SIGMA-ALDRICH, St. Louis, USA) as the substrate. Amylase was determined using soluble starch (SIGMA-ALDRICH) as the substrate [45]. Lipase activity was measured using a kit (SIGMA-ALDRICH) based on a titrimetric method [46]. For all the enzymatic activities, values obtained were normalised to the protein content of each sample, as estimated by the Lowry's method [47], and expressed as specific activities (Units per mg of protein, $\mathrm{U} \mathrm{mg}^{-1}$ protein). Data were analysed statistically by ANOVA test. Differences were considered statistically significant when $\mathrm{p} \leq 0.05$.

\section{Enzymes from Bacterial Strains}

Bacterial strains isolated from the gastro-intestinal tracts were tested for their biochemical capabilities to hydrolyse different organic compounds by culture method on plates of specific media. In particular, protease activity was determined using casein as the substrate (Skim milk at 2\% final concentration) and measuring the diameter of the clearing zones produced after incubation at $35^{\circ} \mathrm{C}$; gelatinase was as- 
sayed by streaking cultures onto Bacto Nutrient gelatin (Oxoid) plates. Lipase production was tested using Tween 80 (polyoxyethylene sorbitan mono-oleate) as a substrate, at a $1 \%$ final concentration. The ability to hydrolyse starch was assayed in a culture medium containing $1 \%$ starch as the substrate. Activity against elastin was determined after incubation of a liquid culture of bacterial cells with elastin congo red and further spectrophotometric measurement of the optical absorbance of the supernatant fluid at $488 \mathrm{~nm}$. Chitinase was determined using plates of a medium containing $2 \%$ shrimp and crab shell powder as the major carbon source.

\section{RESULTS}

\section{Influence of Dietary Composition and Nutritional Habit}

The nature and composition of the diet administered strongly affects the metabolic capabilities of fish, so that the administration of different diets may yield to a diversification in the distribution of digestive enzymes. This issue, investigated in axillary seabream specimens divided into experimental groups and fed a protein-rich diet compared with a non-proteic one, showed that enzymatic profiles reflected dietary composition. In fact, a diet rich in proteins, such as fish offals (diet A), resulted in higher amounts of proteases in the specimens assayed, while amylase and lipase levels were greater in fish fed diet B, containing higher percentages of non-proteic compounds in its composition (Fig. 1).

In nutritional research, another interesting issue concerns the replacement of fish oil with vegetable oil, regarded as important dietary ingredient. This consideration lead us to investigate the effect on the digestive enzymes of blackspot seabream of linum and echium seed oils, included in the dietary composition, as a source of polyunsaturated fatty acids (n-3). No significant differences in the behaviour of digestive enzymes were observed at starvation as well as $4 \mathrm{hrs}$ after feeding (Tables 1A, B).

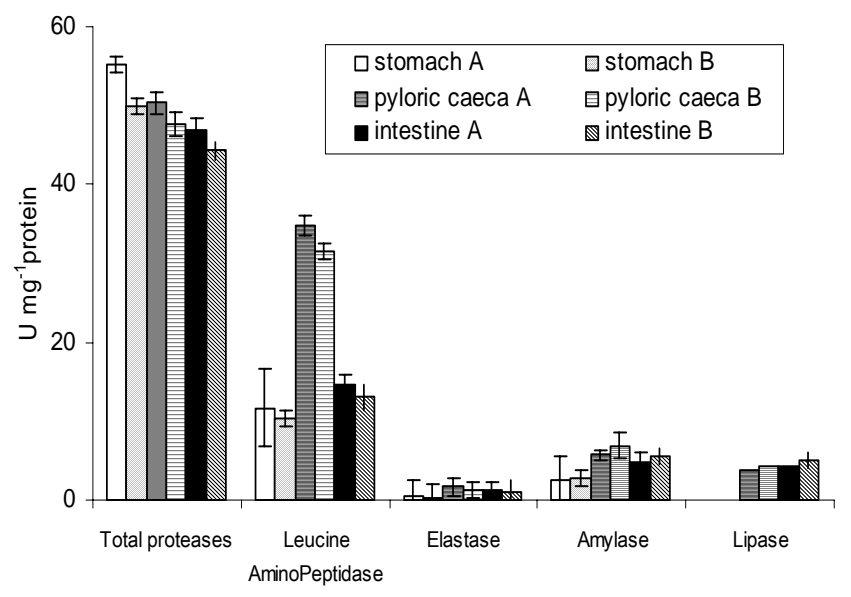

Fig. (1). Average values of digestive enzymes detected in the organs of specimens $(n=5)$ of axillary seabream Pagellus acarne (Risso) fed with diet A (fresh offals) compared with those measured in specimens fed with diet B (non-proteic diet).

Fish fed a diet supplemented with fish oil showed a significant reduction of pepsin content in the stomach, compared with fish fed echium oil $(\mathrm{F}=7.02, \mathrm{P}<0.05$, 4hrs after
Table 1A. Enzyme Values (mean \pm s.d., $n=5$ ) Measured at Starvation in Blackspot Seabream Pagellus bogaraveo fed Diet Containing Linum, Fish, Echium Oils, Compared to a Control Diet. Values are Expressed as U mg $^{-1}$ Protein

\begin{tabular}{|c|c|c|c|c|}
\hline \multirow{2}{*}{ Diet } & \multirow{2}{*}{ Enzyme } & \multicolumn{3}{|c|}{ At Starvation } \\
\hline & & Stomach & Pyloric Caeca & Intestine \\
\hline \multirow[t]{8}{*}{ Linum } & Total proteases & $0.361 \pm 0.01$ & $0.582 \pm 0.005$ & $0.221 \pm 0.001$ \\
\hline & Pepsin & $0.188 \pm 0.002$ & $0.00 \pm 0.00$ & $0.00 \pm 0.00$ \\
\hline & Trypsin & $0.00 \pm 0.00$ & $0.084 \pm 0.029$ & $0.074 \pm 0.043$ \\
\hline & Chymotrypsin & $0.00 \pm 0.00$ & $0.082 \pm 0.015$ & $0.001 \pm 0.0003$ \\
\hline & Carboxypeptidase A & $0.0002 \pm 0.0001$ & $0.0002 \pm 0.0004$ & $0.037 \pm 0.009$ \\
\hline & Carboxypeptidase B & $0.00 \pm 0.00$ & $0.005 \pm 0.001$ & $0.002 \pm 0.003$ \\
\hline & Amylase & $0.34 \pm 0.02$ & $0.53 \pm 0.03$ & $0.383 \pm 0.040$ \\
\hline & Lipase & $0.00 \pm 0.00$ & $0.40 \pm 0.10$ & $2.0 \pm 0.10$ \\
\hline \multirow[t]{8}{*}{ Fish } & Total proteases & $1.33 \pm 0.01$ & $8.567 \pm 0.002$ & $3.55 \pm 0.002$ \\
\hline & Pepsin & $0.119 \pm 0.008$ & $0.00 \pm 0.00$ & $0.00 \pm 0.00$ \\
\hline & Trypsin & $0.00 \pm 0.00$ & $0.286 \pm 0.030$ & $0.051 \pm 0.038$ \\
\hline & Chymotrypsin & $0.00 \pm 0.00$ & $0.145 \pm 0.081$ & $0.381 \pm 0.010$ \\
\hline & Carboxypeptidase A & $0.009 \pm 0.01$ & $0.080 \pm 0.060$ & $0.012 \pm 0.002$ \\
\hline & Carboxypeptidase B & $0.0005 \pm 0.00$ & $0.005 \pm 0.002$ & $0.018 \pm 0.012$ \\
\hline & Amylase & $0.36 \pm 0.02$ & $0.463 \pm 0.04$ & $0.345 \pm 0.03$ \\
\hline & Lipase & $0.00 \pm 0.00$ & $0.40 \pm 0.10$ & $0.40 \pm 0.10$ \\
\hline \multirow[t]{8}{*}{ Echium } & Total proteases & $3.03 \pm 0.07$ & $20.54 \pm 0.005$ & $13.07 \pm 0.02$ \\
\hline & Pepsin & $0.475 \pm 0.017$ & $0.00 \pm 0.00$ & $0.00 \pm 0.00$ \\
\hline & Trypsin & $0.00 \pm 0.00$ & $0.132 \pm 0.010$ & $0.082 \pm 0.040$ \\
\hline & Chymotrypsin & $0.00 \pm 0.00$ & $0.064 \pm 0.014$ & $0.086 \pm 0.012$ \\
\hline & Carboxypeptidase A & $0.00 \pm 0.00$ & $0.058 \pm 0.010$ & $0.005 \pm 0.010$ \\
\hline & Carboxypeptidase B & $0.019 \pm 0.013$ & $0.009 \pm 0.0011$ & $0.008 \pm 0.003$ \\
\hline & Amylase & $0.08 \pm 0.005$ & $0.121 \pm 0.010$ & $0.135 \pm 0.01$ \\
\hline & Lipase & $0.00 \pm 0.00$ & $0.40 \pm 0.10$ & $0.80 \pm 0.30$ \\
\hline \multirow[t]{8}{*}{ Control } & Total proteases & $1.289 \pm 0.001$ & $7.85 \pm 0.006$ & $6.97 \pm 0.005$ \\
\hline & Pepsin & $0.363 \pm 0.025$ & $0.00 \pm 0.00$ & $0.00 \pm 0.00$ \\
\hline & Trypsin & $0.00 \pm 0.00$ & $0.028 \pm 0.005$ & $0.071 \pm 0.005$ \\
\hline & Chymotrypsin & $0.00 \pm 0.00$ & $0.546 \pm 0.022$ & $0.072 \pm 0.012$ \\
\hline & Carboxypeptidase A & $0.00 \pm 0.00$ & $0.103 \pm 0.040$ & $0.085 \pm 0.060$ \\
\hline & Carboxypeptidase B & $0.018 \pm 0.017$ & $0.017 \pm 0.007$ & $0.026 \pm 0.002$ \\
\hline & Amylase & $0.09 \pm 0.02$ & $0.139 \pm 0.03$ & $0.104 \pm 0.030$ \\
\hline & Lipase & $0.00 \pm 0.00$ & $2.0 \pm 0.5$ & $0.40 \pm 0.10$ \\
\hline
\end{tabular}

feeding); this depressive effect could induce alterations in the preliminary, gastric, breakdown of dietary components, resulting in the elongation of digestive times. In the same group (fish fed with fish oil), trypsin content in the intestine decreased, although not at a significant level, compared with the control group. Diet containing linum oil caused a decrease in chymotrypsin values in the pyloric caeca and in the intestine; in this organ, an increase in lipase content occurred, while the carboxypeptidase B levels were signifi- 
Table 1B. Enzyme Values (Mean \pm s.d., $n=5$ ) Measured 4 Hours after Feeding in Blackspot Seabream Pagellus bogaraveo Fed Diet Containing Linum, Fish, Echium oils, Compared to a Control Diet. Values are Expressed as $\mathrm{U} \mathrm{mg}^{-1}$ Protein

\begin{tabular}{|c|c|c|c|c|}
\hline \multirow{2}{*}{ Diet } & \multirow{2}{*}{ Enzyme } & \multicolumn{3}{|c|}{ After Feeding (4hrs) } \\
\hline & & Stomach & Pyloric Caeca & Intestine \\
\hline \multirow[t]{8}{*}{ Linum } & Total proteases & $0.517 \pm 0.03$ & $0.896 \pm 0.002$ & $0.489 \pm 0.001$ \\
\hline & Pepsin & $0.688 \pm 0.014$ & $0.00 \pm 0.00$ & $0.00 \pm 0.00$ \\
\hline & Trypsin & $0.00 \pm 0.00$ & $0.088 \pm 0.017$ & $0.045 \pm 0.007$ \\
\hline & Chymotrypsin & $0.00 \pm 0.00$ & $0.090 \pm 0.055$ & $0.007 \pm 0.040$ \\
\hline & Carboxypeptidase A & $0.004 \pm 0.02$ & $0.013 \pm 0.07$ & $0.053 \pm 0.040$ \\
\hline & Carboxypeptidase B & $0.0002 \pm 0.0001$ & $0.041 \pm 0.010$ & $0.011 \pm 0.009$ \\
\hline & Amylase & $0.40 \pm 0.05$ & $0.445 \pm 0.040$ & $0.568 \pm 0.05$ \\
\hline & Lipase & $0.00 \pm 0.00$ & $3.20 \pm 0.30$ & $2.0 \pm 0.2$ \\
\hline \multirow[t]{8}{*}{ Fish } & Total proteases & $1.944 \pm 0.001$ & $13.72 \pm 0.004$ & $12.03 \pm 0.005$ \\
\hline & Pepsin & $0.059 \pm 0.021$ & $0.00 \pm 0.00$ & $0.00 \pm 0.00$ \\
\hline & Trypsin & $0.00 \pm 0.00$ & $0.033 \pm 0.007$ & $0.013 \pm 0.017$ \\
\hline & Chymotrypsin & $0.00 \pm 0.00$ & $0.140 \pm 0.042$ & $0.108 \pm 0.042$ \\
\hline & Carboxypeptidase A & $0.00 \pm 0.00$ & $0.099 \pm 0.050$ & $0.064 \pm 0.009$ \\
\hline & Carboxypeptidase B & $0.184 \pm 0.104$ & $0.153 \pm 0.027$ & $0.082 \pm 0.065$ \\
\hline & Amylase & $0.43 \pm 0.04$ & $0.441 \pm 0.037$ & $0.452 \pm 0.030$ \\
\hline & Lipase & $0.00 \pm 0.00$ & $5.60 \pm 0.60$ & $0.80 \pm 0.10$ \\
\hline \multirow[t]{8}{*}{ Echium } & Total proteases & $7.84 \pm 0.06$ & $24.36 \pm 0.09$ & $17.51 \pm 0.003$ \\
\hline & Pepsin & $0.847 \pm 0.005$ & $0.00 \pm 0.00$ & $0.00 \pm 0.00$ \\
\hline & Trypsin & $0.00 \pm 0.00$ & $0.073 \pm 0.002$ & $0.110 \pm 0.013$ \\
\hline & Chymotrypsin & $0.00 \pm 0.00$ & $0.431 \pm 0.059$ & $0.144 \pm 0.024$ \\
\hline & Carboxypeptidase A & $0.00 \pm 0.00$ & $0.053 \pm 0.020$ & $0.041 \pm 0.03$ \\
\hline & Carboxypeptidase B & $0.00 \pm 0.00$ & $0.087 \pm 0.072$ & $0.089 \pm 0.018$ \\
\hline & Amylase & $0.12 \pm 0.01$ & $0.234 \pm 0.02$ & $0.276 \pm 0.022$ \\
\hline & Lipase & $0.00 \pm 0.00$ & $6.40 \pm 0.50$ & $2.80 \pm 0.20$ \\
\hline \multirow[t]{8}{*}{ Control } & Total proteases & $3.04 \pm 0.05$ & $15.51 \pm 0.03$ & $11.58 \pm 0.03$ \\
\hline & Pepsin & $0.293 \pm 0.004$ & $0.00 \pm 0.00$ & $0.00 \pm 0.00$ \\
\hline & Trypsin & $0.00 \pm 0.00$ & $0.141 \pm 0.003$ & $0.079 \pm 0.002$ \\
\hline & Chymotrypsin & $0.00 \pm 0.00$ & $0.416 \pm 0.096$ & $0.07 \pm 0.04$ \\
\hline & Carboxypeptidase A & $0.00 \pm 0.00$ & $0.118 \pm 0.12$ & $0.119 \pm 0.010$ \\
\hline & Carboxypeptidase B & $0.017 \pm 0.013$ & $0.108 \pm 0.110$ & $0.113 \pm 0.017$ \\
\hline & Amylase & $0.13 \pm 0.01$ & $0.273 \pm 0.030$ & $0.195 \pm 0.020$ \\
\hline & Lipase & $0.00 \pm 0.00$ & $3.60 \pm 0.30$ & $1.60 \pm 0.20$ \\
\hline
\end{tabular}

cantly reduced $(\mathrm{F}=31.69, \mathrm{P}<0.01$, at starvation). Compared with the control, both linum and fish oils increased significantly amylase levels, particularly in the stomach at starvation $(\mathrm{F}=40.80$ and $57.63, \mathrm{P}<0.01$ respectively). This result suggested that the vegetable nature of the linum oil was effective in stimulating the digestive capabilities of the carbohydrate component.
The effects produced on the digestive enzymes by the inclusion of the rice protein concentrate in the diet of blackspot seabream are reported in Fig. (2).

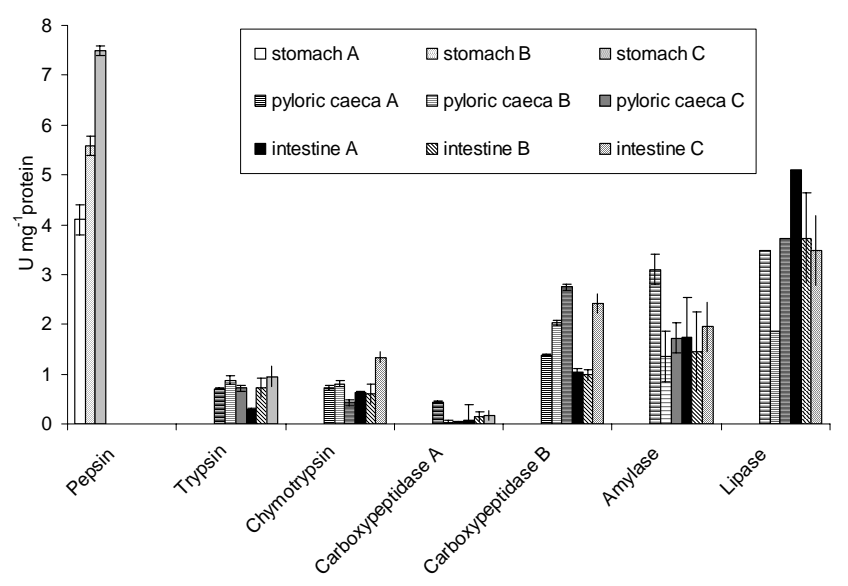

Fig. (2). Digestive enzymes recorded in blackspot seabream Pagellus bogaraveo (Brünich) specimens $(\mathrm{n}=5)$ fed diets A (control diet), $\mathrm{B}$ and $\mathrm{C}$, containing 0,20 and $35 \%$ rice protein concentrate, respectively.

Fish fed with the diet containing the highest level of rice protein concentrate $(35 \%)$ displayed a significant increase of pepsin in the stomach $(\mathrm{F}=448.64, \mathrm{P}<0.01)$ and of trypsin in the intestine $(\mathrm{F}=18.57, \mathrm{P}<0.01)$ (Fig. 2). The same stimulating effect was also observed with the diet containing $20 \%$ of rice protein concentrate. The contents of chymotrypsin, carboxypeptidase A and B values were significantly enhanced in the intestine of fish fed the diet containing $35 \%$ of this compound ( $\mathrm{F}$ versus control diet $=29.40,121.50,15.48$, $\mathrm{P}<0.01$, respectively). Therefore, data obtained suggested the inclusion of this compound as a dietary ingredient for its positive effects on protein digestibility in blackspot seabream.

\section{Effect of the Chronobiology of the Digestion}

In adult specimens of greater amberjack, acid protease of the stomach (pepsin) displayed values of 123 and $124.50 \mathrm{U}$ $\mathrm{mg}^{-1}$ protein at starvation and $4 \mathrm{hrs}$ after feeding (Fig. 3A). At the same digestive phases, alkaline proteases were 142.50 and $152.50 \mathrm{Umg}^{-1}$ protein in the pyloric caeca and 137.50 and $150 \mathrm{U} \mathrm{mg}^{-1}$ protein in the intestine, respectively. In all the examined organs, the levels of proteases $6 \mathrm{hrs}$ after feeding were similar to those measured in an empty stomach (Fig. 3A). Leucine aminopeptidase content varied from 53.5 to $84.5 \mathrm{U} \mathrm{mg}^{-1}$ protein in the stomach, respectively at starvation and $4 \mathrm{hrs}$ after feeding; from 121.0 to $129.0 \mathrm{U} \mathrm{mg}^{-1}$ protein in the pyloric caeca and from 99.0 to $116.5 \mathrm{U} \mathrm{mg}^{-1}$ protein in the intestine, respectively (Fig. 3A).

Elastase content varied from 0.03 to $1.00 \mathrm{U} \mathrm{mg}^{-1}$ protein in the stomach; from 1.50 to $2.30 \mathrm{U} \mathrm{mg}^{-1}$ protein in the pyloric caeca and from 0.65 to $1.55 \mathrm{U} \mathrm{mg}^{-1}$ protein in the intestine (Fig. 3B). 


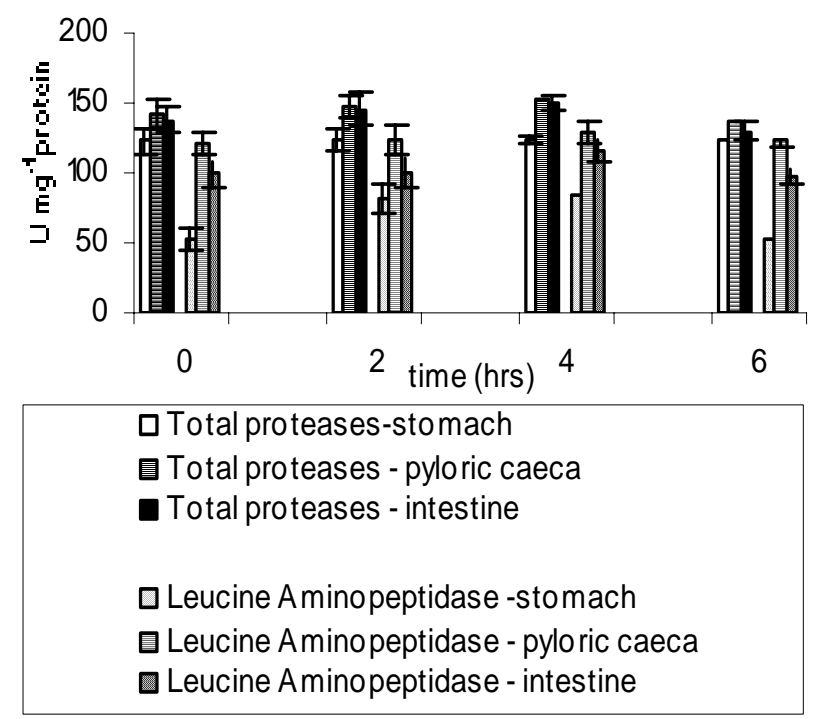

Fig. (3A). Average values of total proteases and leucine aminopeptidase measured at time 0 , after 2 days of starvation, and 2, 4, 6 hrs after feeding, in the organs of greater amberjack Seriola dumerilii (Risso) specimens $(n=5)$ fed with fresh offals.

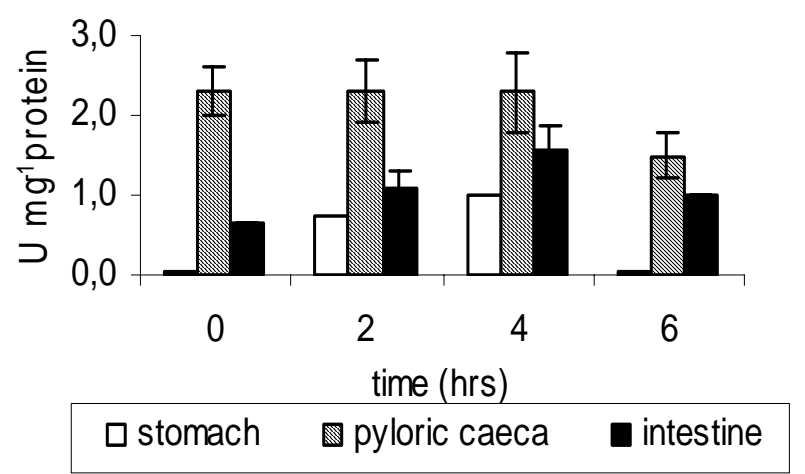

Fig. (3B). Average values of elastase measured in the organs of greater amberjack Seriola dumerilii (Risso) specimens fed with fresh offals. See Fig. 3A for caption.

Amylase showed values of 0.04 and $0.35 \mathrm{U} \mathrm{mg}^{-1}$ protein in the stomach, 0.28 and $0.40 \mathrm{U} \mathrm{mg}^{-1}$ protein in the pyloric caeca and 0.18 and $0.35 \mathrm{U} \mathrm{mg}^{-1}$ protein in the intestine, at starvation and $4 \mathrm{hrs}$ after feeding, respectively (Fig. 3C).

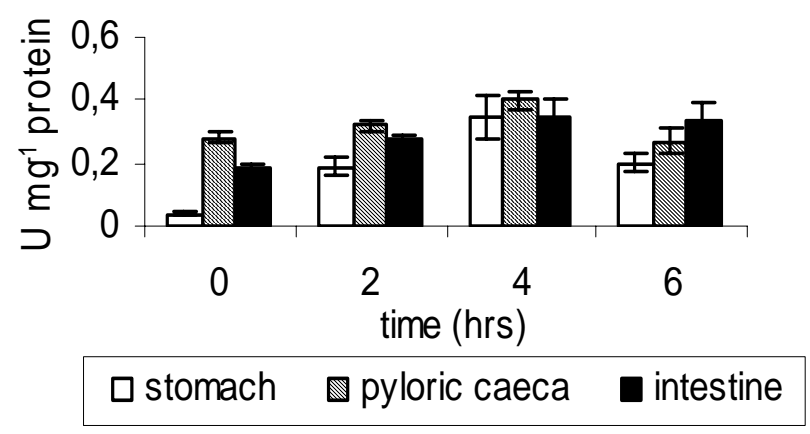

Fig. (3C). Average values of amylase measured in the organs of greater amberjack Seriola dumerilii (Risso) specimens fed with fresh offals. See Fig. 3A for caption.
At the same sampling conditions, lipase activity was 3.30 and $3.75 \mathrm{U} \mathrm{mg}^{-1}$ protein in the pyloric caeca and 5.35 and $4.00 \mathrm{U} \mathrm{mg}^{-1}$ protein in the intestine (Fig. 3D).

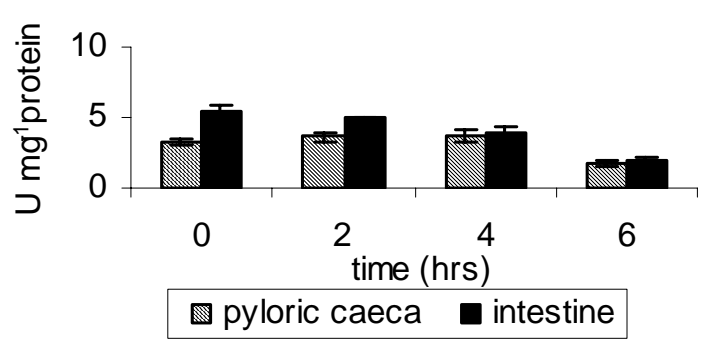

Fig. (3D). Average values of lipase measured in the organs of greater amberjack Seriola dumerilii (Risso) specimens fed with fresh offals. See Fig. 3A for caption.

\section{Contribution of Bacteria to Fish Digestive Capability}

Estimations, carried out in the stomach of greater amberjack, of the specific composition of bacterial flora and of its capacity to degrade organic macromolecules (Figs. 4a, A) showed that, in this fish species, on average $30 \%$ of gastric bacteria play a significant role in the digestive capability. A similar result was observed in the intestine (Figs. 4b, B), where bacterial decomposition was particularly enhanced with respect to the proteolytic activity towards gelatin, casein and elastin.

The high density of bacteria able to degrade complex molecules (average value $10^{5} \mathrm{CFU} \mathrm{\textrm {g } ^ { - 1 }}$ of homogenate) pointed out how microorganisms were actively involved in the breakdown of organic substrates into simple molecules within the digestive tract of fish.

a
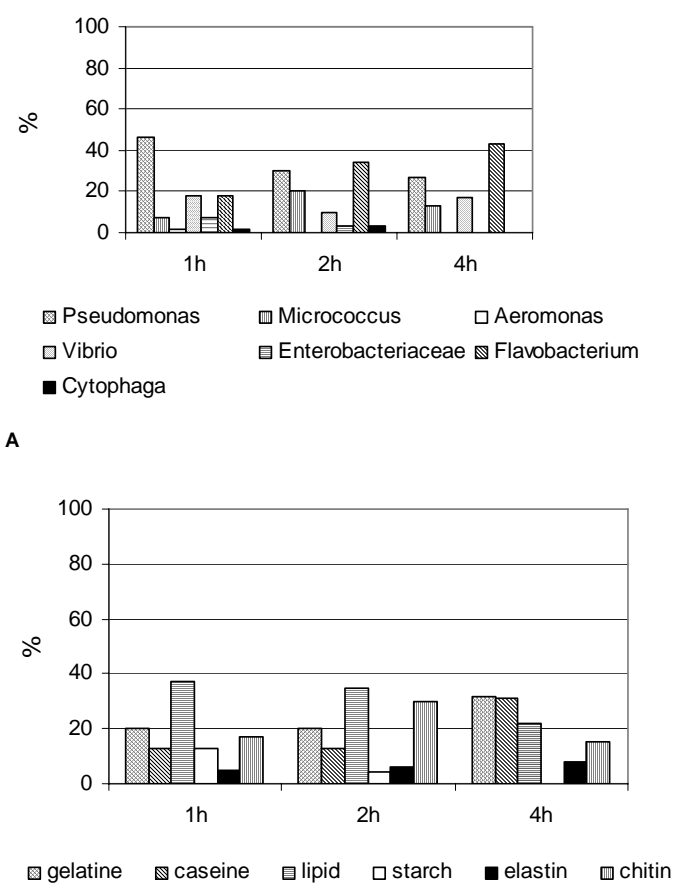

Figs. (4 a, A). Composition (a) and activity of degradation on organic substrates (A) of the microbial community found in the stomach of greater amberjack Seriola dumerilii (Risso). 
Six hours after feeding, the bacterial flora belonging to Vibrio genus increased in the intestine (Figs. 4b, B), showing that a selection in the bacterial composition took place together with an intensification of metabolic versatility. At this digestive phase ( $6 \mathrm{hrs}$ after feeding), the decomposition activity of the microflora increased, concurrently with a decrease in the amount of native (endogenous) enzymes to level similar to those detected during starvation. This trend suggested that bacteria were mainly responsible for the late digestive phases ( 6 hrs after feeding), while biochemical degradation accounted for the assimilation of organic substrates already in the early digestive phases, 2- $4 \mathrm{hrs}$ after feeding.

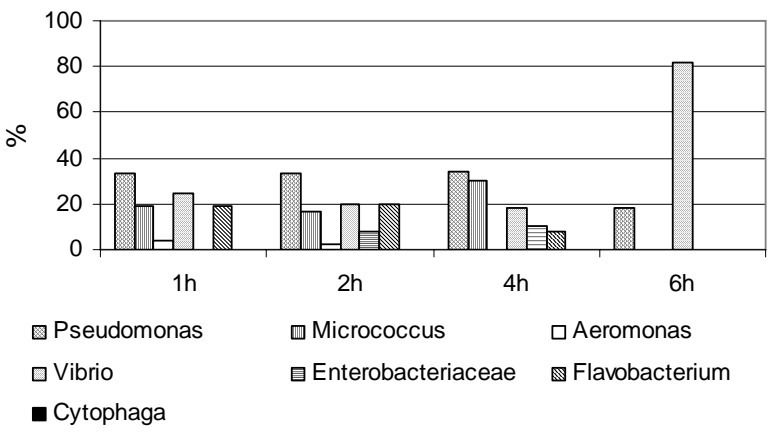

B

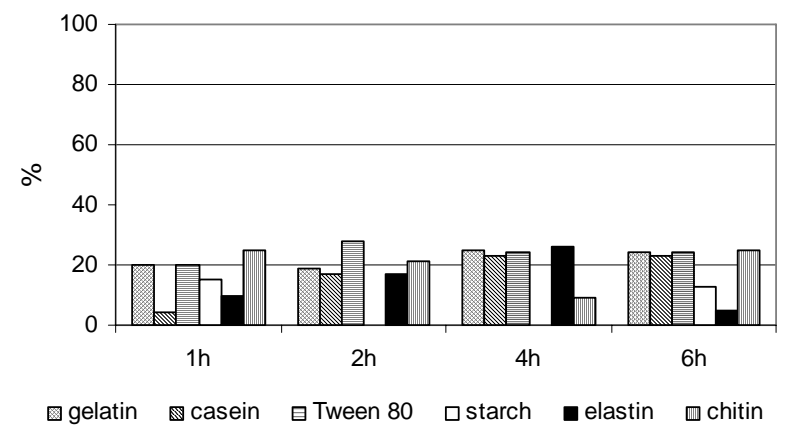

Figs. (4 b, B). Composition (b) and activity of degradation on organic substrates (B) of the microbial community found in the intestine of greater amberjack Seriola dumerilii (Risso)

In blackspot seabream (Figs. 5a, b), the qualitative study of the microbial flora occurring in the different organs of the digestive tract showed the highest bacterial densities in the pyloric caeca $\left(2.34 \times 10^{6} \mathrm{CFU} \mathrm{g}^{-1}\right)$, followed by stomach and intestine. Motile and glucose fermenting microorganisms, belonging to Vibrio and Pseudomonas genera, were predominant in the intestine and pyloric caeca, while strains belonging to Flavobacterium were detected mostly in the stomach. The microflora found in the pyloric caeca displayed gelatinolytic, lipolytic and amylolytic capabilities; strains able to degrade chitin were observed mostly in the intestine (Figs. 5a, b).

\section{Effect of Life Stage}

A preliminary investigation of the digestive enzymatic activities was performed during the first 45 days of development of common pandora larvae fed live prey.
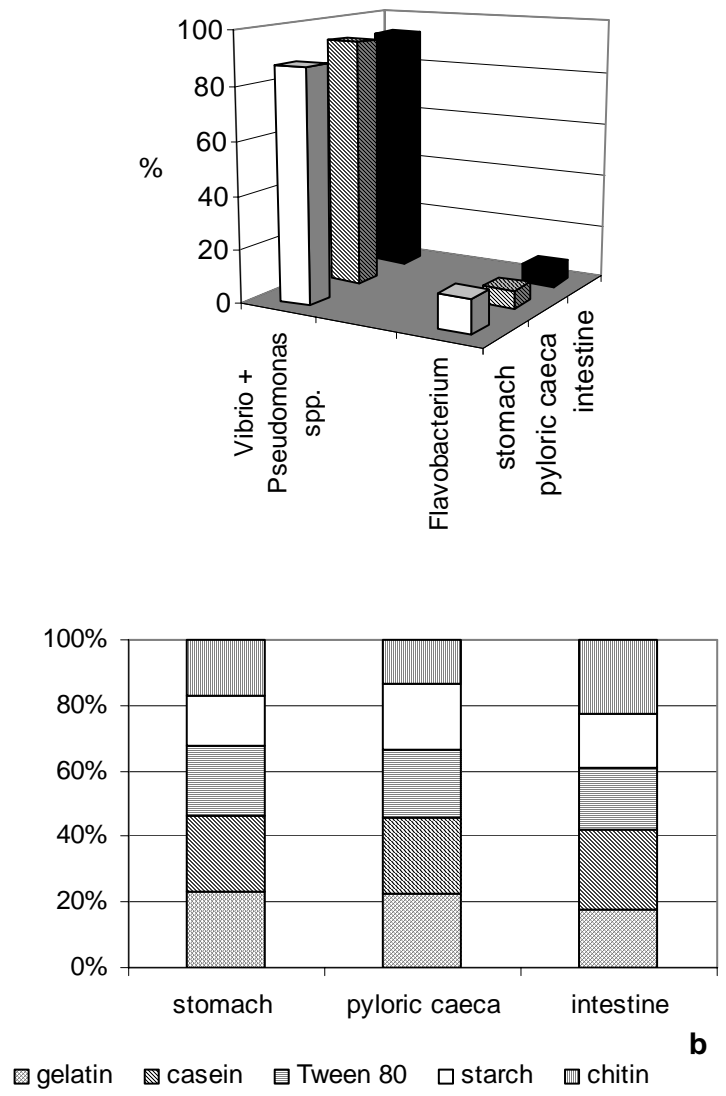

Figs. (5 a, b). Composition (a) and activity of degradation on substrates (b) of the microbial community found in the stomach, pyloric caeca and intestine of blackspot seabream Pagellus bogaraveo (Brünnich).

In the sampled larvae, the increases observed in length (from 1 to $15 \mathrm{~mm}$ ) and in weight (from 0.07 to $2.48 \mathrm{~g}$ ) from hatching $(0 \mathrm{DAH})$ to the end of the experiments $(45 \mathrm{DAH})$ were paralleled by morphological differentiation of the digestive tract in oesophagus, stomach, midgut and hindgut (not shown in Figures).

Qualitative variations in the distribution of digestive enzymes were recorded, in relation to the functional differentiation of the digestive tract. As shown in Fig. (6), from 0 to $17 \mathrm{DAH}$, the total proteolytic activity prevailed at alkaline pHs, whilst between 24 and $31 \mathrm{DAH}$, the percentage of the acid protease increased, predominating over the alkaline ones during the final stages (38-45 DAH).

Table 2 reports the enzymatic values detected during the larval growth of common pandora, showing enzymatic levels increasing with the age. At day 45 the pepsin content was on average nine times higher than that of day 3. In the early stages, lipase was not detectable, suggesting a poor lipid metabolism; larvae showed increased ability to hydrolyse lipids from day 31 .

\section{Species Diversity}

In Epinephalus spp., the enzymatic patterns suggested a higher enzyme availability and a more diversified enzyme distribution along the digestive tract of grouper than in dusky 

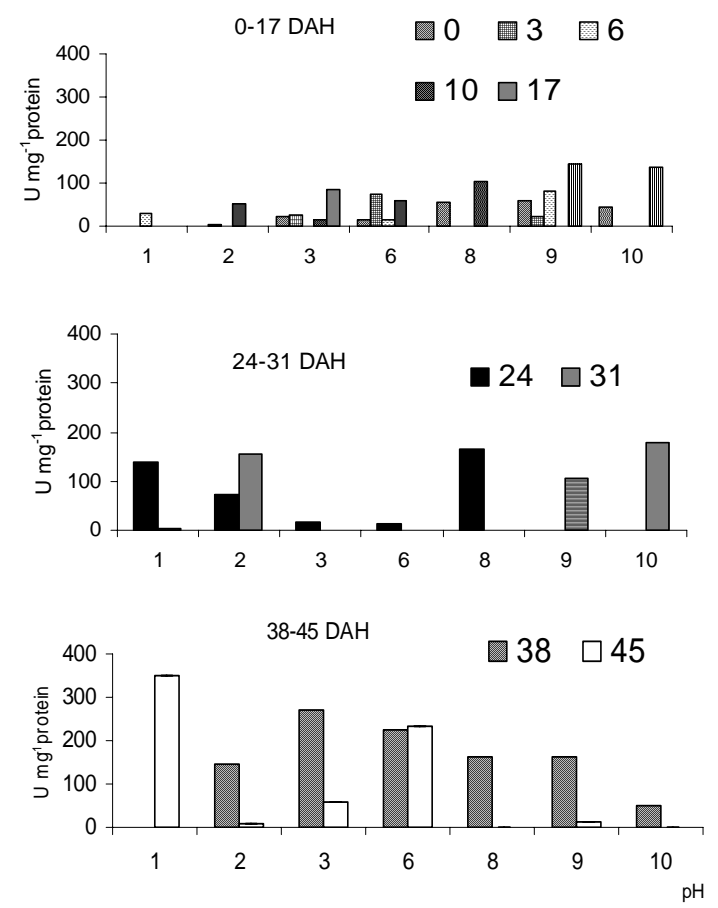

Fig. (6). $\mathrm{pH}$ dependence of proteolytic activity during the larval development of common pandora Pagellus erythrinus L. $(\mathrm{n}=100)$.

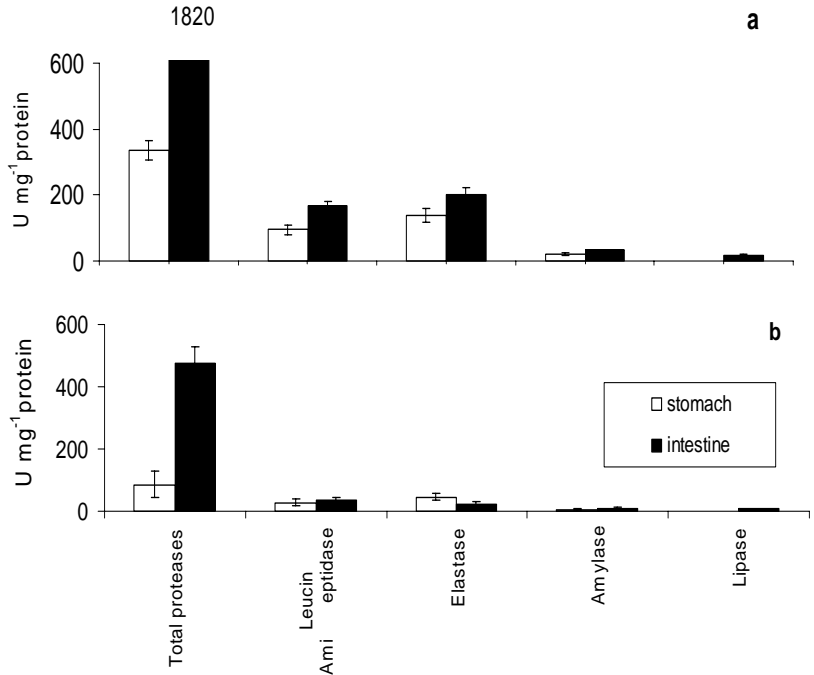

Figs. (7 a, b). Digestive enzymes detected in the stomach and intestine of specimens $(n=5)$ of grouper Epinephalus aenaeus (Geoffrey St Hilaire)(a) and dusky grouper E. marginatus (b) (Lowe).

the acquisition of basic knowledge on this field of research. On the other hand, the determination of digestive enzymes in Sparid fish has a wide interest, due to the importance of cul-

Table 2. Enzyme Values (Mean \pm s.d., $\mathbf{n}=100$ ) Measured During the Larval Development of Common Pandora Pagellus erythrinus L. Values are Expressed as $\mathrm{U} \mathrm{mg}^{-1}$ Protein

\begin{tabular}{|c|c|c|c|c|c|c|c|}
\hline $\begin{array}{c}\text { Days After } \\
\text { Hatching }\end{array}$ & Pepsin & Trypsin & Chimotrypsin & Carboxypep. A & Carboxypep.B & Amylase & Lipase \\
\hline \hline 0 & $0.27 \pm 0.00$ & $0.15 \pm 0.00$ & $0.19 \pm 0.03$ & $0.06 \pm 0.00$ & $0.03 \pm 0.00$ & $0.04 \pm 0.00$ & $0.00 \pm 0.00$ \\
\hline 3 & $0.34 \pm 0.01$ & $0.16 \pm 0.00$ & $0.22 \pm 0.01$ & $0.06 \pm 0.00$ & $0.04 \pm 0.01$ & $0.06 \pm 0.00$ & $0.00 \pm 0.00$ \\
\hline 6 & $0.42 \pm 0.01$ & $0.17 \pm 0.00$ & $0.29 \pm 0.01$ & $0.07 \pm 0.00$ & $0.04 \pm 0.03$ & $0.07 \pm 0.00$ & $0.00 \pm 0.00$ \\
\hline 10 & $0.65 \pm 0.00$ & $0.19 \pm 0.01$ & $0.32 \pm 0.04$ & $0.07 \pm 0.00$ & $0.05 \pm 0.00$ & $0.15 \pm 0.01$ & $0.00 \pm 0.00$ \\
\hline 17 & $0.68 \pm 0.01$ & $0.21 \pm 0.05$ & $0.45 \pm 0.01$ & $0.08 \pm 0.00$ & $0.07 \pm 0.00$ & $0.15 \pm 0.02$ & $0.00 \pm 0.00$ \\
\hline 24 & $1.01 \pm 0.00$ & $0.21 \pm 0.07$ & $0.69 \pm 0.01$ & $0.09 \pm 0.01$ & $0.09 \pm 0.00$ & $0.17 \pm 0.02$ & $0.00 \pm 0.00$ \\
\hline 31 & $2.11 \pm 0.07$ & $0.22 \pm 0.01$ & $0.72 \pm 0.03$ & $0.09 \pm 0.00$ & $0.09 \pm 0.00$ & $0.17 \pm 0.00$ & $7.35 \pm 0.45$ \\
\hline 38 & $2.35 \pm 0.01$ & $0.25 \pm 0.02$ & $0.99 \pm 0.02$ & $0.13 \pm 0.08$ & $0.10 \pm 0.01$ & $0.26 \pm 0.00$ & $7.35 \pm 0.23$ \\
\hline 45 & $2.80 \pm 0.01$ & $0.34 \pm 0.00$ & $1.78 \pm 0.02$ & $0.18 \pm 0.01$ & $0.11 \pm 0.00$ & $1.24 \pm 0.03$ & $9.80 \pm 0.13$ \\
\hline
\end{tabular}

grouper (Figs. 7 a, b). In both the species, the highest levels of total proteases, leucine aminopeptidase and amylase were detected in the intestine, whereas in dusky grouper elastase predominated in the stomach.

\section{DISCUSSION}

This study is a first attempt to review the information existing on digestive enzymes in some emerging Teleost species for the Mediterranean productions. Data from several species that are considered of potential interest for fish farming have been collected, with the objective of contributing to turing these fish as potential resource for the Mediterranean market.

To date, current understanding of digestive patterns in new potential "candidates" for future diversification of Mediterranean aquaculture is still highly fragmentary and incomplete (i.e. Diplodus puntazzo [17, 19]; Pagellus spp. [48-49]). This is in contrast with the wide knowledge available on traditionally intensively reared species such as sea bass [50], sea bream [6, 18, 51-53] and rainbow trout $[6,54]$.

This review focuses on particular features concerning the digestive capability of some selected Teleost species, such as 
those related to diet composition, digestive phases, life stages, contribution of bacterial enzymes to the decomposition of food ingredients, and the species diversity.

\section{Response of Enzymatic Patterns to Dietary Composition}

Fish may adapt their metabolic functions to the dietary substrates, through a regulation in enzyme secretion, in order to improve the utilisation of feed ingredients. The enzyme profiles found in axillary seabream fed two different diets confirmed this consideration. A similar result was observed by Hofer [55, 56] and Reimer [4] for proteases and amylases.

\section{Temporal Variations in Enzymatic Distribution During Digestive Process}

Changes occurring in the secretory response after feeding may provide useful insights on the evolution of the digestive process. Till now, only a few studies have investigated the changes in enzyme patterns which take during digestion in some fish species such as carp, Cyprinus carpio [57], rainbow trout Oncorhynchus mykiss [58], Japanese (Anguilla japonica, [59]) and European (Anguilla anguilla [60]) eel, African catfish Clarias gariepinus [61] and Atlantic salmon Salmo salar [62]. In greater amberjack, enzymatic activities showed a peak $4 \mathrm{hrs}$ after feeding, followed by a decrease at levels similar to those detected at starvation. A possible explanation for this trend is the occurrence of enzymatic denaturation or not reversible bound between enzyme and substrate.

\section{Role of Bacteria In Fish Digestion}

Previous studies [63-66] have underlined the importance of microbes associated to the gastro-intestinal mucosa as key players in digestive processes. Microbial distribution observed in greater amberjack showed how intestinal microbes may provide an important contribution to the digestion and nutrition of fish, releasing nutrients for intestinal absorption. From the enzymatic profiles detected in amberjack and blackspot seabream, we concluded, in agreement with Sera [67], that bacteria, initially introduced with food, further become adapted to particular gastro-intestinal environmental conditions, and develop as a distinct even if transient community of facultative aerobic and anaerobic bacteria, which, being metabolically active, play an active role in digestive processes.

\section{Ontogeny of Digestive Enzymes}

Many recent studies have focused on the determination of digestive enzymes in marine fish larvae; they aimed at describing different aspects of the physiology of the larval digestive tract such as digestive enzyme profiles as well as changes occurring in the metabolic processes during the ontogeny of the digestive tract; the relationships between larval nutrition and development have also been investigated [see 68-70 for reviews on nutritional physiology in larvae and juveniles].

During the first month of life, the gut of common pandora larvae underwent morphological changes that are related to the transition from endo- to exogenous feeding, as commonly observed in fish species [71, 72]. The regional differentiation of the digestive tract is generally associated with the secretion of specific enzymes [73]. The predominance of the acid protease in the late stages (24-31 DAH) was not surprising, because sub-mucosal gastric glands proliferated considerably at this stage, allowing a more efficient digestive process. At the earliest stages of development, common pandora larvae displayed high levels of trypsin and chymotrypsin; this was similar to what found in other species [74]. Trypsin content increased with increasing age, in contrast with turbot larvae [75]. The increase observed in larval enzymatic contents with increasing age agreed with those reported for other fish species $[74,76]$ and could be related to the folding of the intestinal epithelium, that increased the surface available for absorption during fish growth $[37,77]$.

\section{Species Diversity}

Results obtained during comparative studies are not absolute and may not be directly comparable with those reported by other references, due to the broad variety of techniques and to the different modalities of enzyme extraction (by scraping of the gastrointestinal mucosa or by homogenizing the whole digestive tract) which cause variability in the final values [6]. Nevertheless, some useful considerations for optimising nutritional protocols may be inferred from the whole data set obtained during our research, schematised in Table 3.

In greater amberjack, the decrease of proteases along an antero-posterior gradient [25] is consistent with the patterns recorded in other fish species [78, 79]; this means that gastric proteolysis contributes largely to the total proteolytic capability. The result could depend on warm water temperature; in fact, in the related Seriola quinqueradiata seasonal changes were found, with higher trypsin and chymotrypsin activities in the intestinal contents and lower pepsin activity in the stomach contents at low water temperatures [80]. The low amylase levels measured in the stomach of greater amberjack are in agreement with that observed in other carnivorous fish, confirming the existence of a close relationship between amylase activity and feeding habits $[6,52]$.

Comparison between enzyme activities measured in axillary seabream, blackspot seabream and common pandora [29] revealed that the distribution of digestive enzymes changed in relation to the specific diversity.

In the juveniles of blackspot seabream the enzymatic contents in the gastrointestinal tract were in the same order of magnitude as those previously measured in adult specimens $[22,29]$. In the three Sparid species, digestive enzymes were measured at different levels, showing significantly $(\mathrm{P}<$ $0.01)$ lowest contents and therefore the lowest digestive ability in blackspot seabream compared to axillary seabream and common pandora (Table 3). In particular the low levels of proteases found in blackspot seabream would indicate that in this fish protein digestion is potentially poor. As a consequence, blackspot seabream could require for the digestion a time longer than similar species, with a longer time of retention of digesta along the gastrointestinal tract and a lower growth efficiency. Conversely, in axillary seabream the detection of high levels of proteases, among which particularly leucine aminopeptidase, suggest that this species can easily 
Table 3. Comparison Between the Enzyme Levels Detected in the Organs of New Candidate Fish Species for Aquaculture. Data are Reported as $\mathrm{U} \mathrm{mg}^{-1}$ Protein

\begin{tabular}{|c|c|c|c|c|c|c|}
\hline Enzyme & \multicolumn{6}{|c|}{ Stomach } \\
\hline Pepsin & nd & nd & $0.36 \pm 0.03$ & nd & nd & nd \\
\hline Trypsin & nd & nd & $0.00 \pm 0.00$ & nd & nd & nd \\
\hline Carboxyp. A & nd & nd & $0.00 \pm 0.00$ & nd & nd & nd \\
\hline Carboxyp. B & nd & nd & $0.02 \pm 0.01$ & nd & nd & nd \\
\hline Leuc. Aminopep. & $53.5 \pm 0.33$ & $26.17 \pm 1.08$ & nd & $15.43 \pm 1.32$ & $95.09 \pm 21.0$ & $28.77 \pm 14.0$ \\
\hline Elastase & $0.03 \pm 0.00$ & $0.67 \pm 0.02$ & nd & $2.50 \pm 0.27$ & $139.04 \pm 12.0$ & $46.47 \pm 15.0$ \\
\hline Lipase & \multicolumn{4}{|c|}{ Pyloric caeca } & & \\
\hline Enzyme & S. dumerilii & P. acarne & P. bogaraveo & P. erythrinus & & \\
\hline Tot. proteases & $142.5 \pm 0.02$ & $349.5 \pm 8.1$ & $7.85 \pm 0.006$ & $299.5 \pm 3.08$ & & \\
\hline Pepsin & nd & nd & $0.00 \pm 0.00$ & nd & & \\
\hline Trypsin & nd & nd & $0.03 \pm 0.01$ & nd & & \\
\hline Chymotrypsin & nd & nd & $0.55 \pm 0.02$ & nd & & \\
\hline Carboxyp. A & nd & nd & $0.10 \pm 0.04$ & nd & & \\
\hline Lipase & \multicolumn{6}{|c|}{ Intestine } \\
\hline Enzyme & S. dumerilii & P. acarne & P. bogaraveo & P. erythrinus & E. aenaeus & E. marginatus \\
\hline Tot. proteases & $137.5 \pm 10.01$ & $352.5 \pm 3.1$ & $6.97 \pm 0.01$ & $368.5 \pm 4.1$ & $1819.0 \pm 12.0$ & $477.6 \pm 34.0$ \\
\hline Pepsin & nd & nd & $0.00 \pm 0.00$ & nd & nd & nd \\
\hline Trypsin & nd & nd & $0.07 \pm 0.01$ & nd & nd & nd \\
\hline Chymotrypsin & nd & nd & $0.07 \pm 0.01$ & nd & nd & nd \\
\hline Carboxyp. A & nd & nd & $0.08 \pm 0.06$ & nd & nd & nd \\
\hline Carboxyp. B & nd & nd & $0.03 \pm 0.01$ & nd & nd & nd \\
\hline Leuc. Aminopep. & $99.00 \pm 0.90$ & $29.02 \pm 0.91$ & nd & $25.18 \pm 1.44$ & $166.03 \pm 4.0$ & $34.27 \pm 21.0$ \\
\hline Elastase & $0.65 \pm 0.01$ & $2.06 \pm 0.03$ & nd & $1.41 \pm 0.16$ & $200.56 \pm 13.0$ & $22.12 \pm 6.0$ \\
\hline Amylase & $0.18 \pm 0.01$ & $12.46 \pm 0.50$ & $0.10 \pm 0.03$ & $20.05 \pm 1.60$ & $31.95 \pm 0.06$ & $7.88 \pm 0.03$ \\
\hline Lipase & $5.35 \pm 0.09$ & $9.89 \pm 2.31$ & $0.40 \pm 0.10$ & $12.53 \pm 0.28$ & $18.2 \pm 0.05$ & $7.5 \pm 0.03$ \\
\hline
\end{tabular}


grow on diets rich in proteins. In grouper, the high levels of proteases compared to the other examined species (Table 3) confirmed the great ability of this species to digest dietary proteins.

Concerning the enzyme distribution along the digestive tract, while in axyllary seabream a large fraction of proteolytic activity was found in the stomach, in blackspot seabream, as well as in common pandora, protease levels were higher in the intestine than in the other organs [29]. A similar enzymatic distribution was detected along the digestive tract of Sparids (sharpsnout seabream Diplodus puntazzo (Cetti) [17]. Amylase and leucine aminopeptidase were measured in higher amounts in the pyloric caeca of axillary seabream and blackspot seabream, while lipase was detected at the highest levels of in the intestine of axillary seabream and common pandora.

\section{Practical Application of Enzymatic Data for Setting Up Feeding Protocols}

Knowledge of the digestive capability of reared species is necessary for adapting dietary formulation to the functionality of the digestive tract and represents one of the most important objectives of research in fish nutrition [25]. As digestive enzymes can be used as surrogate parameters to predict the ability of fish to use different nutrients, in vitro measurements of digestive enzymatic activity may allow to adapt artificial feeding to the nutritional needs of fish [54].

In greater amberjack, the detection of low amylase levels suggests that carbohydrate digestion is not so efficient; such a consideration may be helpful for the production of manufactured, dried feeds specific for greater amberjack. Conversely, the amylase equipment found in some Pagellus species such as $P$. erythrinus (Table 3) would represent for those species a good strategy for utilising diversified feeding resources, as previously observed [48].

As an example of potential utilisation of the enzymatic data to optimise feeding practices, from values obtained in seabream species some suggestions about the choice of both time intervals and nature (fresh or dried) of food administered can be derived. Experimental evidence of the suitability of rice protein concentrate (RPC) as a new protein ingredient for blackspot seabream feeding in substitution of fish meal was provided by the recorded enzyme levels [23]. RPC seemed to exert a stimulatory effect on proteolytic activity, in contrast with the depressing effect observed in a previous study performed in rainbow trout (unpublished data); the effects induced by RPC are supposed to depend on the same, proteic, nature of this ingredient [23]. Conversely, in the same species enzymatic patterns suggested that the inclusion of linum oil in the diet could improve carbohydrate digestibility only.

In larval common pandora [28], the functional differentiation of the digestive tract is coupled with the secretion of specific enzymes, supporting a good efficiency of digestion. The high amount of pepsin and chymotrypsin, but also amylase and lipase found in the examined samples, confirmed that pandora larvae are well equipped with digestive enzymes already before first exogenous feeding. Therefore pandora larvae have a good digestive capacity, which made them potentially able to digest, absorb and metabolise endogenous food of different biochemical composition, independent from live prey ingestion. Consequently, exogenous proteases from live food (rotifers) are supposed to contribute scarcely to the digestive process, in disagreement with what previously observed in other fish larvae [74, 75]. The basic evaluation of the functional status of larval fish gut represents the initial step for defining the optimal rearing conditions of this species [28]. Due to the increasing tendency to replace live food with inert microdiets, knowledge of larval digestive ability of this species and of the qualitative and quantitative variations in the distribution of digestive enzymes during the first development stages is likely to improve the performances of larval rearing and to contribute to weaning success of common pandora.

\section{CONCLUSIONS}

Research on the metabolic processes related to digestion in reared fish is still in progress and, in those species currently farmed, the status of research on digestive physiology is far from a complete picture on the process of nutrient hydrolysis. Therefore, further investigations on digestive enzymes are required to improve knowledge existing on their interaction with different factors intrinsic to fish nutrition (such as dietary composition or growth stage); all these features can offer interesting perspectives for further studies, with exciting and promising applicative purposes for aquaculture development. The clarification of aspects intrinsic to the digestive physiology, such as the definition of the enzymatic pattern typical of a selected fish species, the chronobiology of the digestion and the evolution of the digestive organs during fish growth can provide useful contributions to the field of fish nutrition.

\section{ACKNOWLEDGMENTS}

Research was funded by Italian Ministry for Agriculture and Forest Policies (MIPAF) within the $5^{\text {th }}$ Three-years plan of research and experimentation.

\section{REFERENCES}

[1] Phillips AM Jr. Nutrition, digestion and energy utilization. In: Hoar WS, Randall DJ, Ed. Fish Physiology. Academic Press: London 1969; pp. 391-432.

[2] Buddington RK, Krogdahl A, Bakke-Mckellep AM. The intestine of carnivorous fish: structure and functions and the relations with diet. Acta Physiol Scandin 1997; 161: 67-80.

[3] Smith LS. Digestion in teleost fish. In: Lectures presented at the FAO/UNPD training course in fish feed technology. ADCP/REP/80/11, 1980; 3-17.

[4] Reimer G. The influence of diet on the digestive enzymes of the amazon fish Matrincha, Bricon cf. melanopterus. J Fish Biol 1982; 21: 637-42.

[5] Ugolev AM, Kuz'mina VV. Fish enterocyte hydrolases. Nutrition adaptations. Comp Biochem Physiol 1994; 107A: 187-93.

[6] Hidalgo MC, Urea E, Sanz A. Comparative study of digestive enzymes in fish with different nutritional habitus. Proteolytic and amylase activities. Aquaculture 1999; 170: 267-83.

[7] Tengjaroenkul B, Smith BJ, Caceci R, Smith SA. Distribution of intestinal enzyme activities along the intestinal tract of cultured Nile tilapia Oreochromis niloticus L. Aquaculture 2000; 182: 31727.

[8] Lundstedt LM, Melo JFB, Santos Neto C, Moraes G. Diet influences proteolytic enzyme profile of the South American catfish Rhamdia quelen. In: International Congress on the Biology of Fish, 
Biochemical and Physiological Advances in Finfish Aquaculture. Vancouver, Canada, 2002.

[9] Seixa Filho JT, Oliveira MGA, Donzele JL, Gomide ATM, Menin E. Atividade de amilase em quimo de três espécies de peixes Telostei de áqua doce. Rev Brasil Zootecnia 1999; 28: 907-913.

[10] Chakrabarti I, Gani MdA, Chaki KK, Sur R, Misra KK. Digestive enzymes in 11 freshwater teleost fish species in relation to food habit and niche segregation. Comp Biochem Physiol 1995; 112A: 167-177.

[11] Chou R-L, Su M-S, Chen H-Y. Optimal dietary protein and lipid levels for juvenile cobia (Rachycentron canadum). Aquaculture 2001; 193: 81-89.

[12] Lovell T. Nutrition and feeding of Fish. Chapman \& Hall: New York 1988.

[13] Halver JE. Fish nutrition, 2nd ed. Academic Press: San Diego 1989.

[14] Hofer R, Schiemer F. Proteolytic activity in the digestive tract of several species of fish with different feeding habits. Oecologia (Berl.) 1981; 48: 342-345.

[15] Jonas E, Ragyansszki M, Olah J, Boross L. Proteolytic digestive enzymes of carnivorous (Silurus glanis L.), herbivorous (Hypophthalmiichthys molitrix Val.) and omnivorous (Cyprinus carpio L.) fishes. Aquaculture 1983; 30: 145-154.

[16] Alarcón FJ, Díaz M, Moyano FJ, Abellán E. Characterization and functional properties of digestive proteases in two sparids; gilthead seabream (Sparus aurata) and common dentex (Dentex dentex). Fish Physiol Biochem 1998; 19: 257-267.

[17] Savona B. Variabilità nei processi enzimatici della digestione in Diplodus puntazzo (Pisces, Sparidae) a diverse condizioni di allevamento. PhD Dissertation, University of Palermo, 1998; 1-72.

[18] Fountoulaki E, Alexis MN, Nengas I, Venou B. Effect of diet composition on nutrient digestibility and digestive enzyme levels of gilthead sea bream (Sparus aurata L.). Aquaculture Research 2005; 36: 1243-1251.

[19] Tramati C, Savona B, Mazzola A. A study of the pattern of digestive enzymes in Diplodus puntazzo (Cetti, 1777) (Osteichthyes, Sparidae): evidence for the definition of nutritional protocols. Aquaculture Int 2005; 13: 89-95.

[20] Caruso G, Genovese L, Greco S. Effect of two diets on the enzymatic activity of Pagellus acarne (Brunnich 1768) in intensive rearing. Eur Aquaculture Soc Spec Publ 1993; 19: 332.

[21] Caruso G, Genovese L, Greco S. Preliminary investigation on the digestive enzymes of reared Pagellus acarne (Risso 1826) juveniles in relation to two different diets. Oebalia 1996; 22: 3-13.

[22] Caruso G, Genovese L, Maimone G, Manganaro A, Mancuso M, Palmegiano GB. Enzimi digestivi in Pagellus bogaraveo: tre diete sperimentali a confronto. Biol Mar Medit 2003: 10: 430-433.

[23] Caruso G, Costanzo MT, Palmegiano GB, Gai F, Genovese L. Blackspot sea bream (Pagellus bogaraveo) fed on rice protein concentrate meal: effect on digestive enzymes. Eur Aquaculture Soc Spec Publ 2005; 35: 158-159.

[24] Caruso G, Genovese L. Attivita' enzimatica nell'apparato digerente di Seriola dumerilii (Risso 1810) in allevamento intensivo. Biol Mar Medit 1993; 1: 257-258.

[25] Genovese L, Patti F, Caruso G. Studies of the digestive cycle in the amberjack (Seriola dumerilii) (Risso 1810) in intensive rearing. Oebalia 1995; 21: 5-15.

[26] Genovese L, Patti F, Caruso G. Intestinal microflora and native enzymes in specimens of Seriola dumerilii (Risso 1810) in intensive rearing: preliminary studies. In Szabò J, Ed. Proceedings of the 2nd International Colloquium Microbiology of Poikilotherms; June 1992; 15-17, Budapest, Hungary.

[27] Caruso G, Genovese L, Monticelli L. Observations on the enzymatic activities in the digestive tract of some Pagellus bogaraveo (Brunnich 1768) specimens in intensive rearing. Oebalia 1999; XXV: 31-42.

[28] Caruso G, Genovese L, Micale V, Spedicato MT, Mancuso M. Preliminary investigation of the digestive enzymes in Pagellus erythrinus (Linneo 1758) larvae. Mar Freshwater Behav Physiol 2001; 34: 265-268.

[29] Caruso G, Genovese L Osservazioni sulla distribuzione degli enzimi digestivi in differenti specie di Sparidi. Biol Mar Medit 2000; 7 : 621-623.

[30] Andaloro F. About the catch, the diet, the reproduction, the size frequencies and distribution of Pagellus acarne (Risso, 1826) in the
Strait of Messina area. Rapp Proc Réun Comm Int Expl Mer Médit 1982; 23: 33-37.

[31] Tortonese E, Ed. Fauna d'Italia. Osteichthyes (Pesci ossei). Vol. II. Bologna: Calderini 1975.

[32] Faranda F, Cavaliere A, Lo Paro G, Manganaro A. Accrescimento di Pagellus acarne alimentati con due diverse diete. Mem Biol Mar Oceanogr 1983; XII: 55-63.

[33] Greco S, Cavaliere A, Lo Paro G, Manganaro A, Sturniolo G, Caridi F. Effetti di diete bilanciate nell'allevamento intensivo di Pagellus bogaraveo (Rovello). Oebalia 1989; XV-2: 637-644.

[34] Micale V \& Genovese L. Supporto della ricerca allo sviluppo di tecniche di acquacoltura per specie innovative: Pagellus erythrinus, Pagellus bogaraveo, Seriola dumerilii. Biol Mar Medit 1998; 5: 1192-1199.

[35] Spedicato MT, Contegiacomo M, Lembo G. Sistemi di produzione innovativi orientati alla maricoltura di nuove specie: Pagellus erythrinus, Pagellus bogaraveo. Biol Mar Medit 1998; 5: 1180-1185.

[36] Papandroulakis N, Divanach P, Anastasiadis P, Kentouri M. The pseudo-green water technique for intensive rearing of sea bream (Sparus aurata) larvae. Aquaculture Int 2001; 9: 205-216.

[37] Ribeiro L, Zambonino-Infante JL, Cahu C, Dinis MT. Development of digestive enzymes in larvae of Solea senegalensis (Kaup 1858). Aquaculture 1999; 179: 465-473.

[38] Anson ML The estimation of pepsin, trypsin, papain and cathepsin with haemoglobin. J Gen Physiol 1938; 22: 79-89.

[39] Hummel BCW. A modified spectrophotometric determination of chymotrypsin, trypsin and thrombin. Can J Biochem Physiol 1959; 37: 1393-1399.

[40] Appel W. Carboxypeptidases. In: Bergmeyer HU, Ed. Methods of Enzymatic analysis. Academic Press 1974; 996-997.

[41] Berger L \& Broida D. The quantitative colorimetric determination in serum and uring of leucine aminopeptidase (LAP). Sigma Technical Bulletin 251, Sigma Chemical Co., St. Louis, Missouri, 1977.

[42] Sachar LA, Winter KK, Sicher N, Frankel S. Photometric method for estimation of elastase activity: Proceedings of the Society for Experimental Biology and Medicine, 1955; 90: 323-326.

[43] Kunitz M. Crystalline soybean trypsin inhibitor. II. General properties. J Gen Physiol 1947; 320: 291-310.

[44] Walter HE. Proteinases: methods with hemoglobin, casein and azocoll as substrates. In: Bergmeyer HU, Ed. Methods of Enzymatic Analysis. Verlag Chemie 1984; 270-277.

[45] Bernfeld P. Amylase $\alpha$ and $\beta$. In: Colowich SP, Ed. Methods in Enzymology. Academic Press 1955; 149-150.

[46] Tietz NW, Fiereck EA. A specific method for serum lipase determination. Clin Chem Acta 1966; 13: 352-358.

[47] Lowry OH, Rosebrough NJ, Farr AL, Randall RJ. Protein measurement with the Folin phenol reagent. J Biol Chem 1951; 193: 265-275.

[48] Fernández I, Moyano FJ, Díaz M, Martínez T. Characterization of $\alpha$-amylase activity in five species of Mediterranean sparid fishes (Sparidae, Teleostei). J Exp Mar Biol Ecol 2001; 262: 1-12.

[49] Ribeiro L, Couto A, Olmedo M, Alvarez-Blazquez B, Linares F, Valente LMP Digestive enzyme activity at different developmental stages of blackspot seabream, Pagellus bogaraveo (Brunnich 1768). Aquaculture Res 2008; 39: 339-346.

[50] Alliot E, Febvre A, Métailler R. Les protéases digestives chez un téléostéen carnivore, Dicentrarchus labrax. Ann Biol Anim Biochem Biophys 1974; $14:$ 229-237.

[51] Munilla-Morán R, Saborido-Rey F. Digestive enzymes in marine species. I. Proteinase activities in gut from redfish (Sebastes mentella), seabream (Sparus aurata) and turbot (Scophthalmus maximus). Comp Biochem Physiol 1996; 113B: 395-402.

[52] Munilla-Morán R, Saborido-Rey F. Digestive enzymes in marine species. II. Amylase activities in gut from seabream (Sparus aurata), turbot (Scophthalmus maximus) and redfish (Sebastes mentella). Comp Biochem Physiol 1996; 113B: 827-834.

[53] Deguara S, Jauncey K, Agius C. Enzyme activities and $\mathrm{pH}$ variations in the digestive tract of gilthead sea bream. J Fish Biol 2003; 62: 1033-1043

[54] Furné M, Hidalgo MC, López A, García-Gallego M, Morales AE, Domezain A, Domezainé J, Sanz A. Digestive enzyme activities in Adriatic sturgeon Acipenser naccarii and rainbow trout Oncorhynchus mykiss. A comparative study. Aquaculture 2005; 250: 391398. 
[55] Hofer R. The adaptation of digestive enzymes to temperature, season and diet in roach, Rutilus rutilus L., and rudd, Scardinius erythrophthalmus L. 1. Amylase. J Fish Biol 1979a; 14: 565-572.

[56] Hofer R. The adaptation of digestive enzymes to temperature, season and diet in roach, Rutilus rutilus L., and rudd, Scardinius erythrophthalmus L. Proteases. J Fish Biol 1979b; 15: 373-379.

[57] Onishi T, Murayama S, Takeuchi M. Changes in digestive enzyme evels in carp after feeding -III. Response of protease and amylase o twice-a-day feeding. Bull J Soc Sci Fish 1976; 42: 921-929.

[58] Fal'ge R, Spannhof L. Amylase, esterase and protease activity in the gut contents of the rainbow trout Salmo gairdneri after feeding. J Ichthyol 1976; 16: 672-677.

[59] Takii K, Shimeno S, Takeda M. Changes in digestive enzyme activities in eel after feeding. Bull J Soc Sci Fish 1985; 51: 20272031.

[60] Caruso G, Denaro MG, Genovese L. Temporal changes in digestive enzyme activities in the gastrointestinal tract of European eel (Anguilla anguilla) (Linneo 1758) following feeding. Mar Freshwater Behav Physiol. 2008; 41: 215-228.

[61] Uys W, Hecht T, Walters M. Changes in digestive enzyme activities of Clarias gariepinus (Pisces: Clariidae) after feeding. Aquaculture 1987; 63: 243-250.

[62] Einarsson S, Davies PS, Talbot C. The effect of feeding on the secretion of pepsin, trypsin and chymotrypsin in the Atlantic salmon, Salmo salar L. Fish Physiol Biochem 1996; 15: 439-446.

[63] MacDonald NL, Stark JR, Austin B. Bacterial microflora in the gastro-intestinal tract of Dover sole (Solea solea $\mathrm{L}$.), with emphasis on the possible role of bacteria in the nutrition of the host. FEMS Microbiol Lett 1986; 35: 107-111.

[64] Cahill MJ. Bacterial flora of fishes: a review. Microb Ecol 1990; 19: 21-41.

[65] Moriarty DJW Interactions of microorganisms and aquatic animals, particularly the nutritional role of the gut flora. In: Lésel R, Ed. Microbiology in Poecilotherms. Elsevier Science Publishers 1990; 217-222.

[66] Stevens CE, Hume ID. Contributions of microbes in vertebrate gastrointestinal tract to production and conservation of nutrients. Physiol Rev 1998; 78: 393-427.

[67] Sera H, Ishida Y, Kadota M. Bacterial flora in the digestive tracts of marine fish. In: Colwell RR, Morita RY, Ed. Effect of the ocean environment on microbial activities. University Park Press 1974; 467-490.
[68] Hofer R, Köck G. Method for quantitative determination of digestive enzymes in fish larvae. Polskie Arch Hydrobiol 1989; 36: 439441.

[69] Kolkovski S. Digestive enzymes in fish larvae and juveniles- implications and applications to formulated diets. Aquaculture 2001; 200: 181-201.

[70] Zambonino Infante JL, Cahu CL. Dietary modulation of some digestive enzymes and metabolic processes in developing marine fish: applications to diet formulation. Aquaculture 2007; 268: 98105.

[71] Sarasquete MC, Polo A, Gonzales De Canales ML. A histochemical and immunochemical study of digestive enzymes and hormones during larval development of the sea bream, Sparus aurata $\mathrm{L}$. The Histochem. J 1993; 25: 430-437.

[72] Baglole CJ, Goff GP, Wright GM. Distribution and ontogeny of digestive enzymes in larval yellowtail and winter flounder. J Fish Biol 1998; 53: 767-784.

[73] Micale V, Caruso G, Garaffo M, Genovese L, Spedicato MT, Muglia U. Morphological development and enzyme activities of the digestive tract in larval pandora, Pagellus erythrinus L. Italian J Anat Embryol 2006; 111: 109.

[74] Lauff M, Hofer R. Proteolytic enzymes in fish development and the importance of dietary enzymes. Aquaculture 1984; 37: 335-346.

[75] Munilla-Morán R, Stark JR, Barbour A. The role of exogenous enzymes in digestion in cultured turbot larvae (Scophthalmus maximus L.). Aquaculture 1990; 88: 337-350.

[76] Govoni JJ, Boehlert GW, Watanabe Y. The physiology of digestion in fish larvae. Environ Biol Fishes 1986; 16: 59-77.

[77] Segner H, Rosch R, Schmidt H, Von Poeppinghausen KJ. Digestive enzymes in larval Coregonus lavaretus L. J Fish Biol 1989; 35: 249-263.

[78] Uys W, Hecht T. Assays on the digestive enzymes of sharptooth catfish, Clarias gariepinus (Pisces: Clariidae). Aquaculture 1987; 63: 301-313.

[79] Ash R. Protein digestion and absorption. In: Cowey CB, Mackie AM, Bell JG, Ed. Nutrition and feeding in fish. Academic Press $1988 ; 69-94$.

[80] Kofuji PYM, Akimoto A, Hosokawa H, Masumoto T. Seasonal changes in proteolytic enzymes of yellowtail Seriola quinqueradiata (Temminck \& Schlegel; Carangidae) fed extruded diets containing different protein and energy levels. Aquaculture Res 2005; 36: 696-703.

(C) Caruso et al.; Licensee Bentham Open.

This is an open access article licensed under the terms of the Creative Commons Attribution Non-Commercial License (http://creativecommons.org/licenses/by-nc/3.0/) which permits unrestricted, non-commercial use, distribution and reproduction in any medium, provided the work is properly cited. 